Jurnal Indonesia Sosial Teknologi: p-ISSN: 2723 - 6609

e-ISSN : 2745 - 5254

Vol. 1, No. 3 Oktober 2020

\title{
ANALISIS PARAMETER PEMESINAN PADA MATERIAL KIMPOSIT MATRIKS EPOXY RESIN BERPENGUAT SERAT KULIT ROTAN
}

\author{
Benny Wahyudi \\ Politeknik Negeri Bandung \\ Email : benny.wahyudi.pmf16@polban.ac.id
}

\begin{abstract}
Composite is one type of material that is currently widely used in the industrial sector. One of the advantages of composites is in their resistance to corrosion and in the relatively easier production process so that the use of composites will be more profitable than using metal. This research is an experimental study using the independent variable, namely the infeed rate, the dependent variable, namely cutting quality, and several other variables as control variables, namely the infeeding depth of $1 \mathrm{~mm}$ and the infeeding movement of $0.05 \mathrm{~mm} /$ tooth and the type of workpiece material in the form of reinforced epoxy resin composites rattan bark fiber. The Vc used in the study was $20 \mathrm{~m} / \mathrm{min}, 40 \mathrm{~m} / \mathrm{min}$ and $60 \mathrm{~m} / \mathrm{min}$. Research and testing is carried out in several stages, including the making of workpiece specimens, specimen testing (hard test, tensile test and impact test), machining with a CNC milling machine, and analysis of cutting quality. The test result data is obtained from secondary data. The highest hardness test results were found in the $40 \%$ composition of $159.28 \mathrm{BHN}$, the highest tensile test results were in the 0/90 direction configuration of $21.65 \mathrm{Mpa}$, and the highest impact test results were found in the $40 \%$ composition of $1.677 \mathrm{~J} / \mathrm{m} 2$. Optimal cutting results in the down milling process with a cutting speed of $60 \mathrm{~m} / \mathrm{min}$.
\end{abstract}

Keywords: cutting speed; composite; cutting quality

\section{Abstrak}

Komposit merupakan salah satu jenis material yang saat ini telah dipergunakan secara luas pada sektor industri. Salah satu keunggulan komposit adalah pada ketahanannya terhadap korosi serta pada proses produksinya yang relatif lebih mudah sehingga pemakaian komposit akan lebih menguntungkan dibandingkan dengan memakai logam. Tujuan penelitian ini adalah untuk menentukan parameter pemesinan yang sesuai supaya di dapatkan hasil pemotongan yang optimal. Penelitian ini merupakan jenis penelitian eksperimen menggunakan variabel bebas yaitu kecepatan pemakanan, variabel terikat yaitu kualitas pemotongan serta beberapa variabel lain sebagai variabel kontrol yaitu kedalaman pemakanan sebesar $1 \mathrm{~mm}$ dan gerakan pemakanan sebesar $0,05 \mathrm{~mm} /$ gigi serta jenis material benda kerja berupa komposit epoxy resin berpenguat serat kulit rotan. Vc yang digunakan dalam penelitian sebesar $20 \mathrm{~m} / \mathrm{min}, 40 \mathrm{~m} / \mathrm{min}$ dan $60 \mathrm{~m} / \mathrm{min}$. Penelitian dan pengujian di lakukan melalui beberapa tahap di antaranya pembuatan spesimen benda kerja, pengujian spesimen (uji keras, uji tarik dan uji impak), pemesinan dengan mesin CNC milling, serta analisis kualitas pemotongan. Data hasil 
pengujian didapat dari data sekunder. Hasil pengujian kekerasan tertinggi terdapat pada komposisi $40 \%$ sebesar 159,28 BHN, hasil pengujian tarik tertinggi terdapat pada konfigurasi arah 0/90 sebesar 21,65 Mpa, serta hasil pengujian impak tertinggi terdapat pada komposisi $40 \%$ sebesar $1,677 \mathrm{~J} / \mathrm{m} 2$. Hasil pemotongan optimal pada proses down milling dengan kecepatan potong sebesar $60 \mathrm{~m} / \mathrm{min}$.

Kata kunci: Kecepatan Potong; Komposit; Kualitas Pemotongan

\section{Pendahuluan}

Kabupaten Cirebon merupakan salah satu daerah di Jawa Barat yang memilki segudang potensi usaha yang terkenal. Potensi usaha masyarakat Cirebon salah satunya potensi kerajinannya, khususnya kerajinan yang berbahan dasar rotan. Kerajinan dan meubel rotan merupakan salah satu produk unggulan kabupaten Cirebon. Rotan memiliki beberapa keunggulan daripada kayu, seperti ringan, kuat, elastis /mudah dibentuk, serta murah. Namun, sejak pengembangan kulit rotan sintetis semakin banyak digunakan, maka penggunaan kulit rotan alami mengalami penurunan. Oleh karena itu perlu di cari pemanfaatan kulit rotan alami karena kulit rotan memiliki nilai ekonomis yang tinggi. Pemanfaatan kulit rotan alami dapat digunakan sebagai bahan pengisi (filler) komposit. Dari pemanfaatan ini diharapkan dapat mengurangi limbah kulit rotan karena tergantikan oleh kulit rotan sintetis. (Kurniadi, Santosa, \& Wilis, 2020) dalam penelitiannya membahas tentang pengaruh komposisi serat rotan terhadap kekerasan dan keuletan material menjelaskan bahwa keuletan material komposit dengan komposisi serat $0 \%$ sebesar $1,096 \mathrm{~J} / \mathrm{m} 2$, komposisi serat $20 \%$ sebesar 1,068 J/m2, komposisi serat $30 \%$ sebesar 1,230 J/m2, sedangkan komposisi $40 \%$ sebesar 1,677 J/m2. (Mulyatno \& Jokosisworo, 2008) yang membahas tentang pengaruh konfigurasi serat kulit rotan terhadap kekuatan tarik yang akan dimanfaatkan dalam pembuatan badan kapal. Hasil pengujian tanpa serat sebesar $12,7 \mathrm{MPa}$, hasil pengujian tarik arah serat $0 / 90^{\circ}$ sebesar 21,65 MPa dan nilai kekuatan. Dalam penelitian lain Noerhamzah yang membahas tentang pengaruh gerak makan dan putaran spindel terhadap keausan pahat HSS pada proses pemesinan end milling komposit berpenguat serat nanas. Pada penelitiaan ini dilakukan proses pemesinan freis dengan kedalaman $1 \mathrm{~mm}$ dengan gerak makan yang digunakan yaitu $0,496 \mathrm{~mm} /$ putaran, $0,744 \mathrm{~mm} /$ putaran serta $1,041 \mathrm{~mm} /$ putaran lalu putaran spindel yaitu $140 \mathrm{rpm}, 204 \mathrm{rpm}$ serta $283 \mathrm{rpm}$. Kemudian dilihat pengaruh dari gerak makan dan kecepatan spindel terhadap keausan pahat HSS (Davis, 2019). Berdasarkan penelitian Ardhiyanto yang membahas tentang analisis kekuatan tarik, puntir, kekerasan dan komposisi kimia baja ST 60 sebagai material propeller setelah perlakuan carburizing dengan variasi temperatur pemanasan. Kesimpulan dari penelitian ini adalah nilai kekuatan tarik raw material sebesar $730 \mathrm{MPa}$ serta kekerasan baja ST 60 sebesar 177,67 HV (Ardhiyanto, Budiarto, \& Santosa, 2018). Dari beberapa penelitian yang sudah dilakukan sebelumnya masing-masing mempunyai perbedaan disesuaikan dengan hasil dan penjelasan dari peneliti. Namun dalam penelitian ini mencoba mendeskripsikan tantang bagaimana untuk menentukan parameter pemesinan yang sesuai supaya di dapatkan hasil pemotongan yang optimal. Berdasarkan penelitian 
Tholib yang membahas tentang pengaruh pengaruh jenis serat terhadap kualitas hasil pemesinan bahan komposit. Pada penelitiaan ini dilakukan proses pemesinan freis dan gurdi dengan jenis material berbeda yaitu komposit serat rubek dan komposit serat gelas. Kemudian dilihat pengaruh dari jenis material terhadap kualitas hasil pemesinan (Thalib \& Husni, 2015).

Berdasarkan penelitian Firman yang membahas tentang studi sifat dan morfologi komposit serat daun nanas epoxy ditinjau dari fraksi massa dengan orientasi serat acak. Kesimpulan dari penelitian ini adalah komposit memiliki kekuatan tarik sebesar 1,07 Mpa (Firman, Muris, \& Junaedi, 2015).

Berdasarkan penelitian Santoso yang membahas tentang analisis mekanik komposit serat gelas pada tabung Cng tipe 2. Kesimpulan dari penelitian ini adalah komposit memiliki nilai kekerasan sisi permukaan sebesar 33,1 HV dan nilai kekasaran pada sisi tebal sebesar 35,5 HV (Santoso, Tauviqirrahman, \& Ismail, 2015). Berdasarkan penelitian Rahman yang membahas tentang pengaruh fraksi volume serat terhadap peningkatan kekuatan impak komposit berpenguat serat nanas-nanasan (bromealiaceae) kontinyu searah dengan matriks unsaturated polyester. Kesimpulan dari penelitian ini adalah kekuatan impak optimal pada fraksi volume 35\% sebesar $0,0046 \mathrm{~J} / \mathrm{mm}^{2}$ (Rahman \& Suwanda, 2010). Berdasarkan penelitian Wardani yang membahas tentang analisis pengujian impak metode izod dan charpy menggunakan benda uji alumunium dan baja ST 37. Kesimpulan dari penelitian ini adalah harga impak pengujian di alat uji hasil rancangan sebesar $1,857 \mathrm{~J} / \mathrm{mm}^{2}$ (Wardani, Samantha, \& Budiman, 2016).

Terdapat kendala yang di hadapi pada proses pengolahan material komposit. Diantaranya adalah menentukan parameter pemesinan yang sesuai supaya didapatkan hasil pemotongan yang optimal. Oleh karena itu, perlu dilakukan penelitian lebih mendalam mengenai parameter pemesinan yang tepat untuk medapatkan kualitas pemotongan yang optimal. Sehingga diharapkan kendala yang terjadi dapat terselesaikan.

\section{Metode Penelitian}

Penelitian ini merupakan penelitian eksperimen menggunakan variabel bebas yaitu kecepatan pemakanan, variabel terikat yaitu kualitas pemotongan serta beberapa variabel lain sebagai variabel kontrol yaitu kedalaman pemakanan sebesar $1 \mathrm{~mm}$ dan gerakan pemakanan sebesar $0,05 \mathrm{~mm} /$ gigi serta jenis material benda kerja berupa komposit epoxy resin berpenguat serat kulit rotan.

\section{A. Metode pengujian keras}

1. Siapkan spesimen uji. Spesimen pengujian kekerasan dibuat dengan 3 buah spesimen untuk masing-masing komposisi serat.

2. Siapkan permukaan benda kerja:

3. Siapkan perangkat uji kekerasan Brinell pada Universal Hardness Tester: 
4. Putar turn wheel searah jarum jam secara perlahan hingga benda kerja menyentuh indentor tanpa mengalami impact, sampai jarum besar berputar sebanyak tiga kali pada skala B dan jarum kecil bergerak dari titik hitam menunju pada titik merah

5. Dorong tuas pembebanan ke arah loading secara perlahan - lahan. Tunggu hingga jarum besar pada skala berhenti dengan sendirinya.

6. Tunggu selama 10 - 15 detik dari saat berhentinya jarum, kemudian gerakkan tuas ke unloading secara perlahan-lahan sampai maksimal. Dengan naiknya tuas, jarum ikut berputar searah putaran jarum jam sampai akhirnya berhenti.

7. Baca harga kekerasan BHN pada saat jarum telah berhenti. Bacalah pada skala BHN yang berwarna hitam.

\section{B. Metode Pengujian Tarik}

1. Mencatat dan menandai dengan nomer benda yang akan diuji.

2. Mencatat ukuran-ukuran benda uji sampai ketelitian $0,1 \mathrm{~mm}$.

3. Memasang benda uji pada penjepit (grip) atas dan bawah pada mesin uji. Diusahakan agar benda uji betul-betul vertikal, kemudian mengencangkan kedua penjepit.

4. Bagian atas mesin tetap (fix) sedangkan bagian bawah bergerak ke bawah dengan kecepatan rendah (konstan).

5. Spesimen tertarik dan mengalami pertambahan panjang $(\Delta \mathrm{L})$

6. Data pertambahan panjang dan beban dapat dilihat pada mesin.

7. Data dicatat dan digunakan untuk membuat diagram tegangan- regangan.

\section{Metode Pengujian Impak}

1. Siapkan dan periksa benda uji. Benda uji dibuat dengan 3 buah spesimen untuk setiap komposisi serat.

2. Buatlah alur takik pada bagian tengah dengan ukuran yang sudah ditentukan menggunakan notching machine. Pengukuran alur menggunakan notch gauge.

3. Ukurlah dimensi dari takik nya mulai dari panjang serta kedalaman nya.

4. Bukalah "the safety lock key".

5. Bukalah "triggers".

6. Rentangkan "the outer tup" dan "the inner tup".

7. Pasanglah benda kerja pada "the V notch".

8. Aturlah jarum dial pada angka nol.

9. Tarik "the spring loaded pin" sambil menghentakkan pada knop pelepas pada "triggers" sampai "outer tup" dan "inner tup" berayun.

10. Bacalah pada dial, besar energi yang diserap oleh batang uji.

\section{Prasyarat material komposit}

1. Kekuatan tarik komposit serat nanas < kekuatan tarik komposit serat kulit rotan < kekuatan tarik baja ST 60

2. Kekerasan komposit serat gelas < kekerasan komposit serat kulit rotan < kekerasan baja ST 60

3. Kekuatan impak komposit serat nanas < kekuatan impak komposit serat kulit rotan < kekuatan impak baja ST 37 


\section{E. Metode pemesinan}

1. Memeriksa kondisi mesin CNC milling agar siap digunakan.

2. Menyiapkan cutter end mill HSS.

3. Menyiapkan material komposit.

4. Memasukkan program kerja pada mesin CNC milling

5. Memasang benda kerja pada ragum dan cutter end mill pada spindle mesin.

6. Memulai proses pengerjaan melalui pemesinan CNC milling.

7. Mengamati hasil pemesinan dengan variasi kecepatan pemotongan

8. Menganalisis dan membahas data penelitian, serta membuat kesimpulan

\section{Hasil dan Pembahasan}

\section{A. Hasil Pengujian Keras}

Menurut Penelitian (Kurniadi et al., 2020) yang membahas tentang pengaruh komposisi serat rotan terhadap kekerasan dan keuletan material. Data hasil pengujian keras dapat dilihat pada tabel 1 .

Tabel 1. Hasil pengujian Keras

\begin{tabular}{|l|l|l|}
\hline No & Komposisi Serat (\%) & Nilai Kekerasan (BHN) \\
\hline 1 & 0 & 140,68 \\
\hline 2 & 20 & 149,98 \\
\hline 3 & 30 & 152,03 \\
\hline 4 & 40 & 159,28 \\
\hline
\end{tabular}

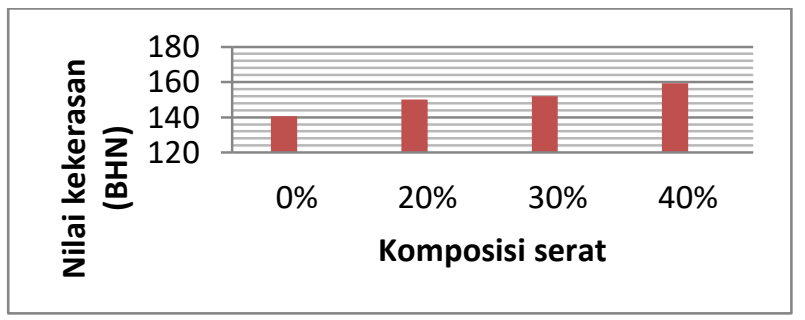

Gambar 1. Karakteristik Pengujian Kekerasan

Kriteria material untuk memenuhi syarat sebagai benda kerja jika memenuhi keadaan sebagai berikut:

Kekerasan komposit serat gelas $=35,5 \mathrm{HV}$

Kekerasan komposit serat kulit rotan $=159,28 \mathrm{BHN}$

Kekerasan ST $37=177,67$ HV

Perlu dilakukan konversi antar satuan kekerasan material. Tabel konversi dapat dilihat pada lampiran.

Data setelah dilakukan koversi satuan sebagai berikut :

Kekerasan komposit serat gelas $=35,5 \mathrm{HV}$

Kekerasan komposit serat kulit rotan $=160 \mathrm{BHN}$

Kekerasan ST $37=177,67 \mathrm{HV}$

$35,5 \mathrm{HV}<160 \mathrm{HV}<177,67 \mathrm{HV}$ 
Jadi, dapat disimpulkan bahwa material komposit serat kulit rotan memenuhi persyaratan sebagai benda kerja dalam proses pemesinan.

\section{B. Hasil Pengujian Tarik}

Menurut penelitian (Mulyatno \& Jokosisworo, 2008) yang membahas tentang pengaruh konfigurasi serat kulit rotan terhadap kekuatan tarik yang akan dimanfaatkan dalam pembuatan badan kapal. Data hasil pengujian tarik dapat dilihat pada tabel 2 .

Tabel 2. Hasil Pengujian Tarik

\begin{tabular}{|l|l|l|}
\hline No & $\begin{array}{l}\text { Konfigurasi } \\
\text { Serat }\end{array}$ & $\begin{array}{l}\text { Nilai Kekuatan } \\
\text { Tarik(MPa) }\end{array}$ \\
\hline 1 & Tanpa Serat & 12,7 \\
\hline 2 & Arah 0/90 & 21,65 \\
\hline 3 & Arah 45 & 21,032 \\
\hline
\end{tabular}

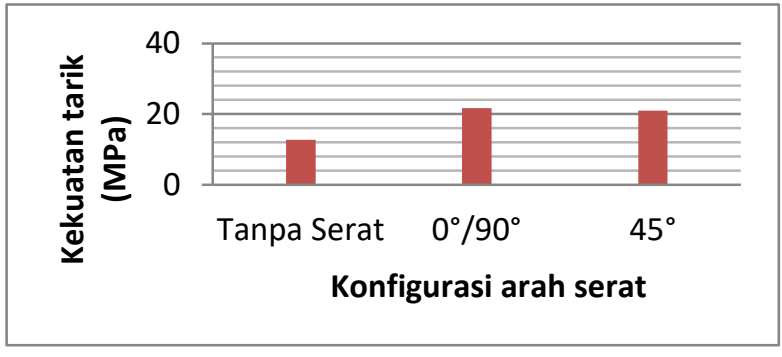

Gambar 2. Karakteristik Pengujian Tarik

Uji prasyarat material

Kekuatan tarik komposit serat nanas $=1,07 \mathrm{MPa}$.

Kekuatan tarik serat kulit rotan $=21,65 \mathrm{MPa}$.

Kekuatan tarik baja ST $60=730 \mathrm{MPa}$.

$1,07 \mathrm{MPa}<21,65 \mathrm{MPa}<730 \mathrm{MPa}$

Jadi, dapat disimpulkan bahwa material komposit serat kulit rotan memenuhi persyaratan sebagai benda kerja dalam proses pemesinan.

\section{Hasil Pengujian Impak}

Menurut Penelitian (Kurniadi et al., 2020) yang membahas tentang pengaruh komposisi serat rotan terhadap kekerasan dan keuletan material. Data hasil pengujian keras dapat dilihat pada tabel 3. 
Tabel 3. Data hasil pengujian impak

\begin{tabular}{|c|c|c|}
\hline No & Komposisi Serat $(\%)$ & Nilai Keuletan $\left(\mathrm{J} / \mathrm{m}^{2}\right)$ \\
\hline 1 & 0 & 1,096 \\
\hline 2 & 20 & 1,068 \\
\hline 3 & 30 & 1,230 \\
\hline 4 & 40 & 1,677 \\
\hline
\end{tabular}

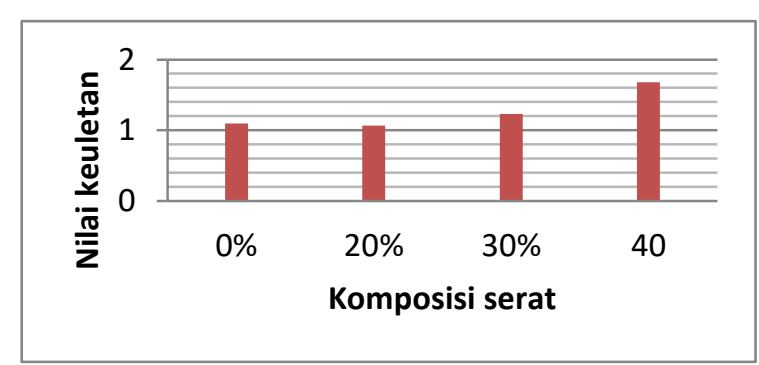

\section{Gambar 3. Karakteristik Pengujian Impak}

Uji prasyarat material

Nilai impak komposit serat nanas $=0,0046 \mathrm{~J} / \mathrm{mm} 2$

Nilai impak komposit serat kulit rotan $=1,677 \mathrm{~J} / \mathrm{mm} 2$

Nilai impak baja ST $37=1,857 \mathrm{~J} / \mathrm{mm} 2$

$0,0046 \mathrm{~J} / \mathrm{mm} 2<1,677 \mathrm{~J} / \mathrm{mm} 2<1,857 \mathrm{~J} / \mathrm{mm} 2$

Jadi, dapat disimpulkan bahwa material komposit serat kulit rotan memenuhi persyaratan sebagai benda kerja dalam proses pemesinan.

\section{Hasil Pengujian Pemesinan}

Tabel 4. Hasil Perhitungan Parameter Pemesinan

\begin{tabular}{|l|l|l|l|l|l|}
\hline No & $\begin{array}{l}\text { Kecepatan } \\
\text { Pemotongan } \\
(\mathrm{m} / \mathrm{min})\end{array}$ & $\begin{array}{l}\text { Proses } \\
\text { Pemesinan } \\
(\mathrm{Up} / \text { Down })\end{array}$ & $\begin{array}{l}\text { Kecepatan } \\
\text { Spindel } \\
(\mathrm{Rpm})\end{array}$ & $\begin{array}{l}\text { Kecepatan } \\
\text { Pemakanan } \\
(\mathrm{mm} / \mathrm{min})\end{array}$ & $\begin{array}{l}\text { Kekasaran } \\
\text { Permukaan } \\
(\mu \mathrm{m})\end{array}$ \\
\hline 1 & 20 & Down & 318,18 & 63,636 & 1,9522 \\
\hline 2 & 40 & Down & 636,36 & 127,272 & 1,9094 \\
\hline 3 & 60 & Down & 954,54 & 190,908 & 1,8848 \\
\hline 4 & 20 & Up & 318,18 & 63,636 & 2,0824 \\
\hline 5 & 40 & Up & 636,36 & 127,272 & 1,9769 \\
\hline 6 & 60 & Up & 954,54 & 190,908 & 1,9177 \\
\hline
\end{tabular}




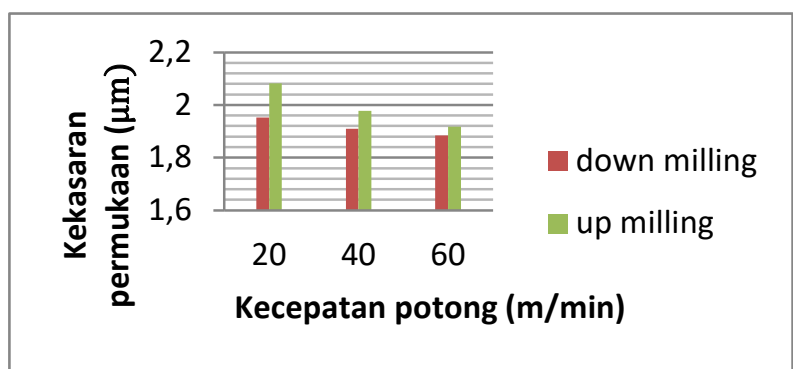

\section{Gambar 4. Karakteristik Kekasaran Permukaan}

\section{E. Simpulan pengujian pemesinan}

Berdasarkan data perhitungan parameter pemesinan yang dilakukan dengan menggunakan variasi pada kecepatan potong serta tipe pemesinan yang digunakan. Hasil pengujian pemesinan tipe down milling dengan kecepatan potong $20 \mathrm{~m} / \mathrm{menit}$ sebesar 1,9552 $\mu \mathrm{m}$, kecepatan $40 \mathrm{~m} /$ menit sebesar 1,9094 $\mu \mathrm{m}$ sedangkan kecepatan $60 \mathrm{~m} / \mathrm{menit}$ sebesar $1,8848 \mu \mathrm{m}$. Untuk tipe up milling dengan kecepatan potong 20 $\mathrm{m} / \mathrm{menit}$ sebesar 2,0824 $\mu \mathrm{m}$, kecepatan $40 \mathrm{~m} /$ menit sebesar 1,9769 $\mu \mathrm{m}$ sedangkan kecepatan $60 \mathrm{~m} /$ menit sebesar $1,9177 \mu \mathrm{m}$.

Kriteria penentuan nilai hasil pemotongan berupa kekasaran permukaan. Semakin besar nilai kekasaran permukaan maka semakin kasar permukaan material, sedangkan semakin kecil nilai kekasaran permukaan maka semakin halus permukaan material. Oleh karena itu kriteria yang dipakai dalam menentukan nilai optimal dari hasil pemotongan berupa nilai semakin kecil semakin baik (small better).

Dari hasil analisa yang dilakukan dengan membandingkan hasil pemotongan berdasarkan pengaruh kecepatan potong serta tipe pemesinan terhadap kualitas pemotongan berupa kekasaran permukaan. Maka didapat nilai optimal dari kualitaas pemotongan berupa kekasaran permukaan terdapat pada kecepatan potong $60 \mathrm{~m} / \mathrm{menit}$ serta tipe pemesinan down milling dengan nilai kekasaran permukaan sebesar $1,8488 \mu \mathrm{m}$.

\section{Kesimpulan}

Berdasarkan seluruh hasil tahapan penelitian yang telah dilakukan, dapat disimpulkan sebagai berikut : 1) Karaktristik material komposit didapat dari beberapa pengujian yaitu pengujian kekerasan, pengujian tarik dan pengujian impak. Hasil pengujian keras material komposit dengan komposisi serat 0\% sebesar 140,68 BHN, komposisi serat 20\% sebesar 149,98 BHN, komposisi 30\% sebesar 152,03 BHN serta komposisi $40 \%$ sebebsar 159,28 BHN. Hasil pengujian tarik material komposit tanpa serat sebesar $12,7 \mathrm{~kg} / \mathrm{mm} 2$, arah serat $0^{\circ} / 90^{\circ}$ sebesar $21,65 \mathrm{~kg} / \mathrm{mm} 2$ serta arah serat $45^{\circ}$ sebesar $21,032 \mathrm{~kg} / \mathrm{mm} 2$. Hasil pengujian impak material komposit dengan komposisi serat $0 \%$ sebesar 1,096 J/m2, komposisi serat 20\% sebesar 1,068 J/m2, komposisi 30\% sebesar 1,230 J/m2 serta komposisi $40 \%$ sebebsar 1,677 J/m2. 2) Hasil pemotongan 
yang optimal didapat dari variasi kecepatan potong yang digunakan pada proses pemesinan. Kecepatan potong tertentu dapat menghasilkan pemotongan yang optimal. Pada proses down milling kecepatan potong $20 \mathrm{~mm} / \mathrm{min}$ menghasilkan Ra sebesar $1,9522 \mu \mathrm{m}$, kecepatan potong $40 \mathrm{~mm} / \mathrm{min}$ menghasilkan Ra sebesar 1,9094 $\mu \mathrm{m}$ serta kecepatan potong $60 \mathrm{~mm} / \mathrm{min}$ menghasilkan Ra sebesar 1,8848 $\mu \mathrm{m}$. Sedangkan pada proses up milling kecepatan potong $20 \mathrm{~mm} / \mathrm{min}$ menghasilkan Ra sebesar 2,0824 $\mu \mathrm{m}$, kecepatan potong $40 \mathrm{~mm} / \mathrm{min}$ menghasilkan Ra sebesar 1,9769 $\mu \mathrm{m}$ serta kecepatan potong $60 \mathrm{~mm} / \mathrm{min}$ menghasilkan Ra sebesar 1,9177 $\mu \mathrm{m}$. 3) Hasil pengujian kekerasan tertinggi terdapat pada komposisi $40 \%$ sebesar $159,28 \mathrm{BNH}$, hasil pengujian tarik tertinggi terdapat pada arah serat $0^{\circ} / 90^{\circ}$ sebesar $21,65 \mathrm{~kg} / \mathrm{mm} 2$ serta hasil pengujian impak tertinggi terdapat pada komposisi $40 \%$ sebesar $1,677 \mathrm{~J} / \mathrm{m} 2$. Hasil pemotongan yang paling optimal adalah menggunakan proses down milling dengan kecepatan potong sebesar $60 \mathrm{~m} / \mathrm{min}$. 


\section{Bibliography}

Ardhiyanto, K. B., Budiarto, U., \& Santosa, A. W. B. (2018). Analisa Kekuatan Tarik, Puntir, Kekerasan dan Komposisi Kimia Baja ST 60 Sebagai Material Poros Propeller Setelah Perlakuan Carburizing Dengan Variasi Temperatur Pemanasan (Metode Experiment). Jurnal Teknik Perkapalan, 6(4).

Davis, N. (2019). PENGARUH GERAK MAKAN DAN PUTARAN SPINDEL TERHADAP KEAUSAN PAHAT HSS PADA PROSES PEMESINAN END MILLING KOMPOSIT BERPENGUAT SERAT NENAS. Universitas Andalas.

Firman, S. H., Muris, M., \& Junaedi, S. (2015). STUDI SIFAT MEKANIK DAN MORFOLOGI KOMPOSIT SERAT DAUN NANAS-EPOXY DITINJAU DARI FRAKSI MASSA DENGAN ORIENTASI SERAT ACAK. Jurnal Sains Dan Pendidikan Fisika, 11(2), 184-191.

Kurniadi, E. R., Santosa, I., \& Wilis, G. R. (2020). Analisa Material Komposit Resin Berpenguat Serat Rotan Untuk Pembuatan Prostesis Kaki Palsu Bagi Penderita Disabilitas. Prosiding Konferensi Ilmiah Mahasiswa Unissula (KIMU) Klaster Engineering.

Mulyatno, I. P., \& Jokosisworo, S. (2008). Analisa Teknis Penggunaan Serat Kulit Rotan Sebagai Penguat Pada Komposit Polimer Dengan Matriks Polyester Yukalac 157 Ditinjau Dari Kekuatan Tarik Dan Kekuatan Tekuk. KAPAL: Jurnal Ilmu Pengetahuan Dan Teknologi Kelautan, 5(3), 173-180.

Rahman, M. B. N., \& Suwanda, T. (2010). Pengaruh Fraksi Volume Serat terhadap Peningkatan Kekuatan Impak Komposit Berpenguat Serat Nanas-Nanasan (Bromeliaceae) Kontinyu Searah dengan Matrik Unsaturated Polyester. Semesta Teknika, 13(2), 137-144.

Santoso, E. F., Tauviqirrahman, M., \& Ismail, R. (2015). Analisis Sifat Mekanik Komposit Serat Gelas Pada Tabung CNG Tipe 2. Jurnal Teknik Mesin, 3(4), 389396.

Thalib, S., \& Husni, H. (2015). PENGARUH JENIS SERAT TERHADAP KUALITAS HASIL PEMESINAN BAHAN KOMPOSIT.

Wardani, C. U., Samantha, Y., \& Budiman, H. (2016). Analisis Pengujian Impak Metoda Izod Dan Charpy Menggunakan Benda Uji Alumunium Dan Baja St37. PROCEEDING STIMA. 